\title{
Diet in the pathogenesis of ischaemic heart disease
}

\author{
A. Stewart Truswell \\ M.D., F.R.C.P., M.F.C.M. \\ Queen Elizabeth College, Campden Hill, London W8 7AH
}

I SHALL start by outlining the central facts in our understanding of the relationship between diet and ischaemic heart disease (IHD). I shall then discuss a series of questions that I am often asked. They are topics which either give people difficulty or are used to show that the need for dietary modification is theoretical and remote from the questioner.

\section{Central facts}

The development of clinical coronary heart disease (CHD) depends upon three processes: atherogenesis, which appears to take years, thrombosis, which probably takes hours and myocardial susceptibility to ischaemia and irritability. Each process must be affected by diet in different ways. The dietary components that affect atherogenesis are the best understood of the three; there is good evidence that habitual diet plays a major role in the slow development of atherosclerosis.

The principal characteristic material that accumulates in the intima in coronary atherosclerosis is esterified and free cholesterol (Böttcher and Woodford, 1962; Abdulla, Adams and Bayliss, 1969). In experimental animals the degree of atheroma produced in different species and on various regimes (dietary and other) appears to depend on the height of the plasma cholesterol concentration $\times$ time (Malmros, 1969; Constantinides, 1960).

In man, the development of clinical CHD has consistently shown a significant positive stepwise relationship with initial plasma cholesterol in all the dozen or so major prospective studies that have been reported (Dayton, 1971; Morris et al., 1966). It is not practical (or ethical) to visualize the extent of coronary arterial disease in most people but post-mortem studies have shown a close relationship between clinical coronary heart disease and the degree of coronary atherosclerosis (Liebow, Bartsch and Insull, 1965; Strong, Solberg and Restrepo, 1968).

Plasma cholesterol can be lowered, in most people with hypercholesterolaemia and in probably all with average cholesterol concentrations, by reducing the saturated fat and cholesterol of the diet (Davidson et al., 1975a). Although several other dietary components can affect plasma cholesterol, they usually do so only in small degree or in special circumstances. If one wants to use a therapeutic diet to lower the cholesterol the coarse tuning is obtained by appropriately altering the dietary fat. The level stays reduced, apparently, so long as the diet is adherecs to (Leren, 1966; Dayton et al., 1969). In differen communities round the world average plasmes cholesterol concentrations correlate well with the percentage of dietary energy from saturated or animal fat (Gordon, 1959; Keys, 1970; Truswell and Mann, 1972). Furthermore, in comparisons between different communities the rate of clinical CHD correlates better with the average saturated or animal fat intake than with any other dietary index (Keys, 1970; Masironi, 1970).

The dietary fat hypothesis, proposed by Ancel Keys in the 1950s (Keys, 1956) can be made into a more realistic scheme if it is used as the backbone and factors other than diet fitted into it. Fig. 1 shows that plasma cholesterol in an individual depends on genetic constitution as well as dietary fat and is influenced by certain drugs, severe mental tension, strenuous exercise as well as other dietary components. Arterial hypertension promotes atherosclerosis just as hypercholesterolaemia does. Exercise

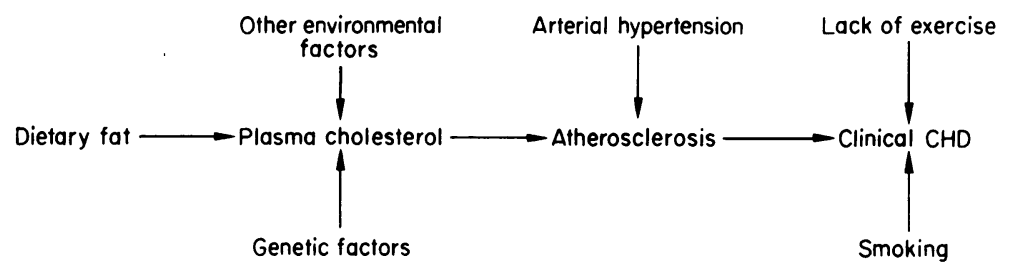

FIG. 1. Augmented dietary fat hypothesis diagram. 
and smoking both appear to act chiefly on the myocardium.

Question 1. When plasma cholesterol is lowered by changing dietary fats, can we be sure that it leaves the body and is not shunted internally (possibly even into the arteries)?

It was first reported in 1957 that faecal bile acid excretion is increased when saturated fats in the diet are replaced by polyunsaturated (Gordon et al., 1957). However, with increasing analytical and metabolic sophistication the picture became confused. Cholesterol balance experiments are technically formidable because of the need to allow for variations in intestinal flow rate, because of the large number of faecal steroids, and the need to distinguish derivatives of plant sterols (present in unrefined polyunsaturated oils) from endogenous cholesterol derivatives. Grundy and Ahrens (1970) at the Rockefeller Institute reported that the increase of faecal bile acids and neutral steroids was insufficient to account for the reduction in plasma cholesterol. On the other hand, Connor (1970), using similar methods, found that the increase of faecal bile acids exceeded the reduction of cholesterol in the plasma compartment of his subjects, who were normal men.

He suggested that the Rockefeller group found little increases of faecal steroids because their subjects had type II hypercholesterolaemia, in which the rate of catabolism of cholesterol to bile acids is probably subnormal (Korman, Ellefson and Hofman, 1975).

Plasma triglycerides also fall as a rule on polyunsaturated fat diets and Lewis and Chait (1974) have evidence that this may be due to decreased very low density lipoprotein (VLDL) synthesis. Since VLDL is converted in the plasma into lowdensity lipoprotein, which carries most of the labile plasma cholesterol, decreased lipoprotein synthesis is an additional mechanism for the effect of polyunsaturated fats on plasma cholesterol. Recently Grundy (1975) reported marked increases in faecal steroids on polyunsaturated fat diets in patients with hypertriglyceridaemia (types IV and V).

The current picture is that increased faecal losses and decreased lipoprotein synthesis probably both operate in most people when the dietary fat is changed from saturated to polyunsaturated but the former effect is small and inconsistent in patients with type II hyperlipidaemia. There is no evidence that cholesterol accumulates anywhere in the body. Indeed in animals, as Dr Armstrong shows elsewhere in this issue (Armstrong, 1976), there is regression of atherosclerotic lesions.
Question 2. How can you explain the lack of correlation between individual fat intake and subsequent CHD in the Framingham study?

The fat intake was obtained from a single history of the usual diet for each individual, with nutrients subsequently estimated from food tables (Kannel and Gordon, 1970). Fat intake is one of the most difficult dietary constituents to estimate (Balogh, Kahn and Medalie, 1971). There was, incidentally, no relationship between the estimated iron intake and haemoglobin concentration in the Framingham study either (Kannel and Gordon, 1970).

In other homogeneous communities, where people have a similar way of life and dietary pattern, correlations have not been found between careful dietary measurements (Keys, 1970; Morris et al., 1963) and the plasma cholesterols of free-living people. This is partly because variation of fat intake is as great with repeat measurements within single individuals as it is between individuals at one time. Then the smaller the real average differences in diet, the stronger become the constitutional and other environmental influences on plasma cholesterol.

When dietary intake and plasma cholesterol levels were measured repeatedly in the members of an Antarctic expedition, correlation between the two could be demonstrated (Easty, 1970). Despite these statistical problems in homogeneous communities, the fact remains that if anyone changes their regular fat intake, plasma cholesterol will show the predicted change, except possibly some resistant cases of type IIa hyperlipoproteinaemia. Differences in mean plasma cholesterol in different communities round the world-from $100 \mathrm{mg} / 100 \mathrm{ml}$ in New Guinea (De Wolfe and Whyte, 1958) to $286 \mathrm{mg} / 100 \mathrm{ml}$ in East Finland (Keys, Karvonen \& Fidanza, 1958)-are mainly attributable to the large differences in quantity and type of their usual fat intake.

Question 3. We have always eaten meat and dairy products in this country, so why has CHD increased so much in the last 40 years?

The incidence of CHD in Britain was first noted around 1925 when Gibson published the first article on myocardial infarction diagnosed during life in a major British journal (Gibson, 1925). After earlier doubts that the rising incidence could be explained by diagnostic awareness, availability of ECG machines and better survival from infections (Campbell, 1963), it is now generally accepted that there is a true epidemic. The increase is clear after standardization for age, and has affected men more than women and Scotland more than England (Department of Health and Social Security, 1974). Neverthe- 
less, occasional cases of CHD have been recorded for centuries, both clinically as angina pectoris (Heberden, 1772) and at post-mortem examination (Liebowitz, 1970).

There has also been a true change in the average diet. Until this century only the aristocracy had a high fat intake. Estimates of national averages by Hollingsworth (1974) show that between 1910 and 1972 consumption of oils and fats doubled from 9 to $18 \%$ of food energy, sugar and syrups increased from 14 to $18 \%$, and dairy products (excluding butter) from 8 to $12 \%$. Meats stayed at $17-18 \%$, while potatoes declined from 7 to $5 \%$ and grain products from 37 to $22 \%$. Even in the last 20 years the National Food Survey shows that the British protein intake has stayed constant while fat has risen and total carbohydrate fallen reciprocally (Department of Health and Social Security, 1974).

Crawford (1968) has pointed out that the meat of wild game contains far less fat and is less saturated than the meat which is available to us today.

Question 4. What about such exceptions to the dietary fat hypothesis as the Masai, who eat fat but have no CHD?

It is well established that the Masai in East Africa have low plasma cholesterol levels. Yet the young men eat large amounts of blood and milk, which should provide a high saturated fat intake. Several observations have been put forward to explain this paradox. The first was that they take a large amount of exercise (Mann, Shaffer and Rich, 1965). They are lean and sometimes need famine relief; they do not have a high fat intake all the year round or throughout life (Shaper, 1972). They appear to have an efficient feedback mechanism for suppressing endogenous cholesterol synthesis on a high cholesterol intake (Ho et al., 1971) and the fat in fermented milk may have a different metabolic effect from butter fat as eaten in Europe (Mann and Spoerry, 1974). All studies in the Masai have been short-term; the present uncertainty about their diet through the years and how it is related to their low plasma cholesterols reflects our general small understanding of the nomadic pastoralist tribes in Africa (Truswell, 1976).

Question 5. Why do different experts give conflicting advice?

If we consider the views of trained scientists, there is now a very substantial consensus. In many of the countries with the highest rates of CHD, experts have been called together and argued out their differing starting opinions. Since 1968 they have produced some fifteen reports, giving their conclusions and recommendations (Department of Health and Social Security, 1974; Medical Boards of Finland, Norway \& Sweden, 1968; Inter Society Commission for Heart Disease Resources, 1972; American Medical Association Council on Foods and Nutrition, 1972; American Heart Association, 1973a; American Health Foundation, 1972; Mayer, 1973; Report of a Committee of the Royal Society of New Zealand, 1971; National Heart Foundation of New Zealand, 1971; National Heart Foundation of Australia, 1974; Australian Academy of Sciences, 1975; International Society of Cardiology: Council on Rehabilitation, 1973; Voedingsraad, 1973; Editorial, 1975; Royal Colleges of Physicians and British Cardiac Society, 1976). In only two of them have there been minority reports by single individuals (Department of Health and Social Security, 1974; Voedingsraad, 1973). The similarities between these recommendations are much greater than their differences. Part of the difference arises from the terms of reference. Some committees confined themselves to dietary recommendations (American Medical Association Council on Foods and Nutrition, 1972; American Health Foundation, 1972; American Heart Association, 1973a; National Heart Founda tion of Australia, 1974; Australian Academy ob Sciences, 1975; Voedingsraad, 1973; Editorial, 1975) while others considered other environmental factors as well (Medical Boards of Finland, Norway and Sweden, 1968; Inter Society Commission for Heart Disease Resources, 1972; Mayer, 1973; National Heart Foundation of New Zealand, 1971; Royal College of Physicians and British Cardiac Society, 1976). One report makes dietary recommendations for health in general, not only to prevent CHD (Medical Boards of Finland, Norway and Sweden, 1968). Then there are two operational approaches. Some committees recommend screening, including routine measurement of plasma lipids, with medical treatment of those found to be at high risk (American Medical Association Council on Foods and Nutrition, 1972; National Heart Foundation of Australia, 1974). Other committees take the public health view and make recommendations for the whole community. All, with possibly one exception (Report of a Committee of the Royal Society of New Zealand, 1971), recommend reduction of saturated fat in the diet.

The Committee on Medical Aspects of Food Policy (Nutrition) of the Department of Health and Social Security in 1974 produced the first official policy statement on diet and CHD in this country. Its advice for the whole population is: that obesity should be prevented or treated; dietary saturated fat should be reduced; sucrose should be reduced if 
only to diminish the risk of obesity; authorities should think carefully before installing water softening plants (Department of Health and Social Security, 1974).

The Committee could not recommend an increase of polyunsaturated fats in the diet 'as a measure intended to reduce the risk of the development of ischaemic heart disease'. They have therefore left people who are not overweight without specific guidance as to what they should eat in place of saturated fat.

Question 6. Should not treatment and prevention of obesity be placed first, as in the DHSS report?

The DHSS report (1974) states 'The order in which the Recommendations follow does not denote our assessment of the ranking of their importance'.

Obesity is a relatively weak and largely indirect risk factor for CHD. The Build and Blood Pressure Study, based on persons examined for life insurance in North America between 1935 and 1953 showed that the risk of CHD was increased by $35 \%$ in obese men compared with $133 \%$ in men with diabetes (Editorial, 1960), and some $300 \%$ in men with plasma cholesterol of 310 compared with $210 \mathrm{mg} /$ $100 \mathrm{ml}$ (American Heart Association, 1973b). The relationship between obesity and CHD is not always consistent; it is not found in all populations (Keys et al., 1972), affects men more than women and involves angina pectoris rather than myocardial infarction (Gordon and Kannel, 1973). When other risk factors which tend to be associated with obesity-hypertension, diabetes and hyperlipidaemia-are held constant, the relationship with CHD becomes very small (Gordon and Kannel, 1973). Obesity is nevertheless a useful and simple clinical sign that indicates an increased likelihood of these factors.

Advice that obesity should be prevented or treated appears in almost all the fifteen official recommendations on diet and CHD. I suspect that one reason why it has appeared so prominently is that there are no special sections of agriculture or food industry that would react to it.

Question 7. Does not the DHSS report suggest that increasing polyunsaturated fat in the diet may be undesirable?

The amount of polyunsaturated fat in the British diet is $5 \%$ of total energy. There is no population which naturally consumes more than $10 \%$ of energy as polyunsaturated fat except Eskimoes living their traditional way of life-and there are few of them nowadays. It is all very well to recommend a diet for which there is no life-long experience to people with increased risk of CHD from hyperlipidaemia, but the DHSS was making recommendations for the general population and so was wise to be cautious.

Several undesirable effects of high polyunsaturated fat intakes have been postulated (Truswell, 1975). Most of these do not stand up to scrutiny; the most important is that there is no increase of malignant neoplasm (Ederer et al., 1971; Heady, 1974). But an increase of gallstones has been reported from the long-term trial in Los Angeles (Sturdevant, Pearce and Dayton, 1973). This needs confirmation, and greater communication between investigators of atherosclerosis and of hepatobiliary disease is desirable (Hofman, Northfield and Thistle, 1973). More work needs to be done, measuring biliary cholesterol, bile acids and phospholipids from duodenal aspiration when dietary fats are changed, e.g. from saturated to polysaturated (Grundy, 1975). No consistent results have been found to date but it is possible that some individuals increase excretion of cholesterol more than bile acids, so producing more lithogenic bile.

On the other hand, advantages are reported for polyunsaturated fats-reduced in vivo arterial thrombosis in animal experiments (Hornstra, 1975), reduced platelet stickiness in man (Hornstra et al., 1973) and lower blood glucose in obese diabetics (Houtsmuller, 1975). Furthermore, if saturated fats are reduced in the diet and replaced by carbohydrate, there will be at least a temporary increase in plasma (fasting) triglycerides (Antonis and Bersohn, 1961).

People do not like a low fat diet (Davidson et al., 1975b). As the West German recommendations put it 'since experience has shown that most consumers are not prepared to reduce their excess fat consumption, there should at least be a partial substitution of saturated fatty acids in the diet by polyunsaturates. An ideal amount in the diet would be $10-15 \%$ of total energy' (Editorial, 1975), and partial replacement of saturated fats by polyunsaturated is the advice given for the general public in their own countries by nine of the fifteen expert committees (Medical Boards of Finland, Norway \& Sweden, 1968; Inter Society Commission for Heart Disease Resources, 1972; American Health Foundation, 1972; American Heart Association, 1973a; Mayer, 1973; Australian Academy of Sciences, 1975; Voedingsraad, 1973; Editorial, 1975; Royal Colleges of Physicians and British Cardiac Society, 1976) the last of which is a second British report on primary prevention of CHD. Another four that only make dietary recommendations for people found to be at increased risk include increased polyunsaturated fat (American Medical Association Council on Foods 
and Nutrition, 1972; National Heart Foundation of New Zealand, 1971; National Heart Foundation of Australia, 1974; International Society of Cardiology: Council on Rehabilitation, 1973).

\section{Question 8. What about dietary cholesterol? Does this increase plasma cholesterol or not?}

There are now enough human data to show that under metabolic unit conditions dietary cholesterol does increase plasma cholesterol concentration. But the effect differs from that of saturated fat in three ways: it is on the whole smaller, there appears to be more individual variation and it is non-linear, with the first $300 \mathrm{mg}$ in the diet having the most effect. This is the part of dietary cholesterol which it is difficult and not usually desirable to eliminate because it is contained in animal cell membranes in meat and fish. Keys maintained for some years (Keys et al., 1956) that exogenous cholesterol had no effect on plasma cholesterol; but with more accumulated data he now accepts that it does (Keys, Grande and Anderson, 1974).

Most of the expert committees recommend that dietary cholesterol should be reduced to $300 \mathrm{mg}$ but the Scandinavian (Medical Boards of Finland, Norway and Sweden, 1968) and both the British reports (Department of Health and Social Security, 1974; Royal Colleges of Physicians and British Cardiac Society, 1976) do not make these recommendations for the general public, which would amount to advice that egg production and consumption should be halved (the present U.K. average is equivalent to four (Food Facts, 1975a) to five eggs (Food Facts, 1975b) per head per week). I do not know of any study that has shown the effect of reducing egg consumption from five to two per week under freeliving or out-patient conditions. And the egg is an excellent source of several nutrients, useful for making meals, not expensive and one of the few foods that we in Britain do not have to import (Food Facts, 1975c).

Question 9. Where does dietary sugar come into all this? Some say that it is important.

There has been special research interest in the dietary sucrose hypothesis in this country, which is where it was proposed (Yudkin, 1964). Sugar has little or no effect on plasma cholesterol (Yudkin, 1968). It does not seem to lead to atheroma formation in experimental animals (Worcester, Bruckdorfer \& Yudkin, 1975; 1975b) and atheroma has regressed on high sugar (low saturated fat) diets (Armstrong, 1976). If compared isocalorically with starch it increases plasma fasting triglycerides in man but only at very high intakes, like $70 \%$ of dietary energy (Macdonald and Braithwaite, 1964). Replacement of the $20 \%$ of sucrose in ordinary Western diets by starch does not lead to any reduction of plasma fasting triglycerides (Mann and Truswell, 1972).

Epidemiological retrospective data from thirty-five countries show a lower correlation between sugar and CHD than saturated fat (Masironi, 1970). There are some countries, such as Mauritius and Venezuela which have high sugar consumption but little CHD. In the eleven communities of the Seven Country prospective study (Keys, 1970) multiple regression analysis showed that although sucrose and saturated fat intakes were correlated, CHD was correlated primarily with the latter (Keys, 1973). No secondary or primary prevention trials involving reduction of dietary sucrose have been reported.

About half the expert committees (Inter Society Commission for Heart Disease Resources, 1972; American Medical Association Council on Foods and Nutrition, 1972; Report of a Committee of the Royal Society of New Zealand, 1971; National Heart Foundation of New Zealand, 1971; National Heart Foundation of Australia, 1974; International Society of Cardiology: Council on Rehabilitation, 1973; Editorial, 1975), have not made any recommendations about dietary sucrose. Five of the others (Medical Boards of Finland, Norway and Sweden, 1968; American Health Foundation, 1972; American Heart Association, 1973a; Australian Academy of Sciences, 1975; Voedingsraad, 1973) towards the end of their list, make such statements as this by the American Heart Association (American Heart Association, 1973a): 'Dependence on foods containing complex natural carbohydrates, such as vegetables, fruits and cereals, is preferable to excessive use of refined sugar such as that contained in candy, soft drinks and other sweets. This recommendation aims at the limitation of concentrated empty calories, i.e. foods providing only calories without vitamins and other essential nutrients'. The remaining three committees (Mayer, 1973; Department of Health and Social Security, 1974; Royal Colleges of Physicians and British Cardiac Society, 1976) give advice which can be illustrated from the Department of Health report: 'The consumption of sucrose, as such or in foods and drinks, should be reduced, if only to diminish the risk of obesity'. Although obese people do not usually eat more sucrose than do lean (Ries, 1973), cutting down sugar in the diet is an easy way of losing some weight (Mann et al., 1970; Mann, Truswell and Manning, 1972).

Question 10. Does the appropriate diet to prevent CHD depend on your genetic plasma lipid type?

There are, of course, at least six types of hyperlipidaemia (Beaumont et al., 1970) and each can be 
subdivided by aetiology or pathogenetic mechanism. But, as Frederickson himself has said, 'it's time to be practical' (Fredrickson, 1975). Specialists in hyperlipidaemia are in short supply; accurate lipoprotein typing requires special laboratory techniques, and establishment of genetic aetiology needs family studies which can be confusing because two or three of the common types can be combined in the same family. Most patients with hyperlipidaemia fall into one of three large groups-hypercholesterolaemia alone, hypertriglyceridaemia alone or a combination of the two.

Screening of the population for hyperlipidaemia would require extensive resources. Though it has been recommended by one committee in the U.S.A. and one in Australia (National Heart Foundation of Australia, 1974), it was not recommended by other bodies in the same countries or either of the two British reports (Department of Health and Social Security, 1974; Royal Colleges of Physicians and British Cardiac Society, 1976). Most cases of CHD occur in people with plasma cholesterol in the 'ordinary' British or American range and the general dietary recommendations (reduced saturated fat, together with reduced calories and/or increased exercise in those who are overweight) are designed to achieve a moderate lowering of the plasma cholesterol, without an increase of the triglycerides, especially if there is partial replacement of polyunsaturated fat. Plasma triglycerides come down quickly when people take up vigorous exercise (Oscai et al., 1972; Truswell and Mann, 1972) or lose weight (Mann et al., 1970). The evidence that hypertriglyceridaemia is independently and prospectively related to the incidence of CHD is not yet established (Heyden, 1975).

When patients are found in the course of medical examination to have lipaemia, or plasma cholesterol well above the ordinary they should, where possible, be managed in consultation with a physician or clinical biochemist experienced in the hyperlipidaemias.

\section{Question 11. Surely other dietary factors are important} as well?

Several other components of the diet may play a role in the pathogenesis of CHD. These attract attention because they are the subjects of current research interests and hypothesis, but there is far less evidence about them and what there is suggests that they are minor factors.

Dietary fibre, whose possible relationship to CHD was suggested by Trowell (1972) consists of four different classes of compounds-cellulose, hemicelluloses, lignins and pectins-of which the last is not fibrous. We find that wheat bran (which contains a mixture of fibrous material) does not lower the plasma cholesterol in man but citrus pectin does (Truswell and Kay, 1975). Much more work needs to be done is this field.

Soft drinking water has been related, not to CHD specifically, but to total cardiovascular mortality. The association has been established in Britain (Crawford, 1972) and confirmed in some eight other countries with reliable vital statistics (Masironi et al., 1973). It is very probable that the balance of trace elements derived both from food and water may be important in the health and irritability of the myocardium. The six British towns which have installed water softening plants have had bigger increases in cardiovascular mortality than the national average (Crawford, Gardner and Morris, 1971). However, exceptions have been reported to the 'water story' in several parts of the U.S.A. (Allwright et al., 1974) and in Australia (Meyers, 1975) and none of the several possible mechanisms for the water effect has yet clearly emerged.

Regular heavy consumption of coffee has been associated with CHD in one prospective study (Paul et al., 1963) and in the retrospective but very large Boston Collaborative Drug Surveillance Program (Jick et al., 1973). On the other hand there have also been negative reports in the U.S.A. (Klatsky, Friedman and Siegelamb, 1973) and none yet from any other country. Standard textbooks have estimated that tea, which is not associated with CHD, should provide about as much caffeine as coffee but with a specific chromatographic method we find that cups of coffee, as consumed, contain nearly twice as much caffeine as cups of tea (AlSamarrae, Ma and Truswell, 1975).

Salt intake appears, mainly in comparison between different communities, to be related to hypertension (Truswell et al., 1972; Dahl, 1973) and some authorities have recommended its restriction as one of the dietary measures to prevent CHD (American Health Foundation, 1972; American Heart Association, 1973a). But the Japanese, who have the highest national salt intake in the world and much hypertension have only $1 / 8$ the CHD mortality of England and Wales and 1/10 the Scottish rate.

\section{Conclusion}

I have attempted to describe the scientific and international background to the dietary recommendations for prevention of CHD which are now available for the general British population (Department of Health and Social Security, 1974; Royal Colleges of Physicians and British Cardiac Society, 1976). These recommendations are clearly going to have implications for medical practice, health educa- 
tion, food manufacturers, food labelling, government food pricing arrangements and British and EEC agricultural policies.

\section{References}

Abdulla, Y.H., Adams, C.W.M. \& Bayliss, O.B. (1969) Relative absence of triglycerides in coronary atherosclerotic lesions. Journal of Atherosclerosis Research, 10, 149.

Allwright, S.P.A., Coulson, A., Detels, R. \& Porter, C.E. (1974) Mortality and water-hardness in three matched communities in Los Angeles. Lancet, ii, 860.

Al-Samarrae, W., MA, M.C.F. \& Truswell, A.S. (1975) Methylxanthine consumption from coffee and tea. Proceedings of the Nutrition Society, 34, 18A.

American Health Foundation (1972) Position statement on diet and CHD. Preventive Medicine, 1, 255.

American Heart Association (1973a) Diet and Coronary Heart Disease. New York: American Heart Association.

American Heart Association (1973b) Coronary Risk Handbook. Estimating Risk of Coronary Heart Disease in Daily Practice. New York: American Heart Association.

American Medical Association Council on Foods and NUTRITION AND FOOD AND NUTRITION BOARD OF THE NATIONAL Research Council (1972) Journal of the American Medical Association, 222, 1647.

Antonis, A. \& Bersohn, I. (1961) The influence of diet on serum triglycerides in South African White and Bantu prisoners. Lancet, i, 3.

ARMSTRONG, M.L. (1976) Evidence of regression of atherosclerosis in primates and man. Postgraduate Medical Journal, 52, 456.

Armstrong, B.K., Mann, J.I., Adelstein, A.M. \& Eskin, F. (1975) Commodity consumption and ischaemic heart disease mortality with special reference to dietary practices. Journal of Chronic Diseases, 28, 455.

Australian ACADEMY OF SCIENCES (1975) Report of a Working Group on Diet and Coronary Heart Disease. Canberra: Australian Academy of Sciences.

Balogh, M., KahN, H.A. \& Medalie, J.H. (1971) Random repeat 24 hour dietary recalls. American Journal of Clinical Nutrition, 24, 304.

Beaumont, J.C., Carlson, L.A., Cooper, A.R. \& FredrickSON, D.S. (1970) Classification of hyperlipidemias and hyperlipoproteinemias. Bulletin of the World Health Organization, 43, 891.

BötrCHER, C.J.F. \& Woodford, F.P. (1962) Chemical changes in the arterial wall associated with atherosclerosis. Federation Proceedings. Federation of American Societies for Experimental Biology, 21 (suppl. II), 15.

CAmpbell, M. (1963) Death rate from diseases of the heart: 1876 to 1959. British Medical Journal, $2,528$.

ConNOR, W.E. (1970) The effect of dietary lipid and sterols on the sterol balance. In: Atherosclerosis. Proceedings of the 2nd International Symposium (Ed. by R.J. Jones), p. 253. Berlin, Heidelberg and New York: Springer Verlag.

Constantinides, P. (1960) Production of advanced cholesterol atherosclerosis in the rabbit. Archives of Pathology, 70, 712.

CRAWFORD, M.A. (1968) Fatty acid ratios in free-living and domestic animals. Possible implications for atheroma. Lancet, i, 1329.

CRAWFORD, M.D. (1972) Hardness of drinking water and cardiovascular disease. Proceedings of the Nutrition Society, 31, 347.

Crawford, M.D., Gardner, M.J. \& Morris, J.N. (1971) Changes in water hardness and local death rates. Lancer, ii, 327.

DAHL, L.K. (1973) Salt and hypertension. American Journal of Clinical Nutrition, 25, 231.
Davidson, S., Passmore, R., Brock, J.F. \& Truswell, A.S. Фి (1975b) Human Nutrition and Dietetics, 6th Edn, p. 88. Edinburgh and London: Churchill Livingstone.

Davidson, S., Passmore, R., Brock, J.E. \& Trusweli, A.S. ¿ (1975) Human Nutrition and Dietetics, 6th Edn, p. 387. C Edinburgh and London:Churchill Livingstone.

DAYTON, S. (1971) Rationale for use of lipid-Jowering drugs. Federation Proceedings. Federation of American Societies $\overline{0}$ for Experimental Biology, 30, 850.

Dayton, S., Hashimoto, S.D., Dixon, W.J. \& TomiYnsu, W (1969) A controlled clinical trial of a diet high in unsaturated fat in preventing complications of atherosclerosis. Circulation, 40 (suppl. II), 1.

DE Wolfe, M.S. \& WHYTE, H.M. (1958) Serum cholesterol œ and lipoproteins in natives of New Guinea and Australians. $\overrightarrow{0}$ Australasian Annals of Medicine, 7, 47.

Department of Health and Social Security (1974) Diet $\overrightarrow{\vec{H}}$ and coronary heart disease. Report of the Advisory Panel $\omega$ of the Committee on Medical Aspects of Food Policy (Nutrition). Report on Health and Social Subjects No. 7. London: H.M. Stationery Office.

EASTY, D.L. (1970) The relationship of diet to serum cho- iv lesterol levels in young men in Antarctica. British Journal of Nutrition, 24, 307.

Ederer, F., Leren, P., TurPeinen, O. \& Frantz, I.D. (1971) Cancer among men on cholesterol-lowering diets. Experience from five clinical trials. Lancet, ii, 203.

EdITORIAL (1960) Mortality among overweight men. Statistical Bulletin Metropolitan Life Insurance Co., February, p. 6.

EDITORIAL (1975) (Federal Republic of Germany recommendations) Dietary fat and degenerative vascular diseases. Nutrition and Metabolism, 18, 113.

Food Facts (1975a) National Food Survey. Household food consumption in the Second Quarter of 1975 (29 Sept London: Ministry of Agriculture, Fisheries and Food.

FOOD FACTS (1975b) Estimates of food supplies moving into consumption in the United Kingdom (3 October) London, Ministry of Agriculture, Fisheries and Food.

FooD FACTS (1975c) United Kingdom sources of supply for food and feeding stuffs (29 October) London, Ministry of Agriculture, Fisheries and Food.

Frederickson, D.S. (1975) It's time to be practical. Circulation, 51, 209.

Gibson, A.G. (1925) The clinical aspects of ischaemic necrosis of the heart. Lancet, ii, 1270.

Gordon, H. (1959) The regulation of the human serumcholesterol level. Postgraduate Medical Journal, 35, 186.

GORDON, T. \& KANNEL, W.B. (1973) The effects of overweight on cardiovascular diseases. Geriatrics, 28, 80.

Gordon, H., Lewis, B., EAles, L. \& Brock, J.F. (1957) Dietary fat and cholesterol metabolism. Faecal elimination of bile acids and other lipids. Lancet, ii, 1299.

GRUNDY, S.M. (1975) Effects of polyunsaturated fats on lipid metabolism in patients with hypertriglyceridemia. Journal of Clinical Investigation, 55, 269.

Grundy, S.M. \& AHRENS, E.H., JR (1970) The effects of unsaturated dietary fats on absorption, excretion, synthesis and distribution of cholesterol in man. Journal of Clinical Investigation, 49, 1135.

Heady, J.A. (1974) Are PUFA harmful? British Medical Journal, 1, 115.

Heberden, W. (1772) Some account of a disorder of the breast. Medical Transactions of the College of Physicians of London, 2, 59.

Heyden, S. (1975) The problem with triglycerides. Nutrition and Metabolism. 18, 1.

Ho, K.J., Biss, K., Mikkelson, B., Lewis, L.A. \& TAYloR, C.B. (1971) The Masai of East Africa: some unique biological characteristics. Archives of Pathology, 91, 387. 
Hofman, A.F., Northfield, T.C. \& Thistle, J.L. (1973) Can a cholesterol-lowering diet cause gallstones? New England Journal of Medicine, 288, 46.

HollingsworTH, D. (1974) Changing patterns of food consumption in Britain. Nutrition Reviews, 32, 352.

HoRNSTRA, G. (1975) Specific effects of types of dietary fat on arterial thrombosis. In: The Role of Fats in Human Nutrition (Ed. by A. J. Vergroesen), p. 303. London and New York: Academic Press.

Hornstra, G., Lewis, B., Chait, A., Turpeinen, O., Karvonen, M.J. \& Vergroesen, A.J. (1973) Influence of dietary fat on platelet function in man. Lancet, $\mathbf{i}, 1155$.

Houtsmuller, A.J. (1975) The role of fat in the treatment of diabetes mellitus. In: The Role of Fats in Human Nutrition (Ed. by A. J. Vergroesen), p. 231. London and New York: Academic Press.

INTER Society Commission for Heart Disease Resources (1972) Primary Prevention of the Atherosclerotic Diseases.

INTERNATIONAL SOCIETY OF CARDIOLOGY: COUNCIL ON ReHABILITATION (1973) Myocardial infarction. How to prevent. How to rehabilitate. Brussels: Council on Cardiac Rehabilitation.

Jick, H., MietTinien, O.S., NefF, R.K., Shapiro, S., Heinonen, O.P. \& SLONE, D. (1973) Coffee and myocardial infarction. New England Journal of Medicine, 289, 63.

KANNEL, W.B. \& Gordon, T. (1970) The Framingham Study. An epidemiological investigation of cardiovascular disease. Section 24. The Framingham diet study: diet and the regulation of serum cholesterol. Washington, D.C.: U.S. Government Printing Office.

KEYS, A. (1956) Diet and development of coronary heart disease. Journal of Chronic Diseases, 4, 364.

KEYS, A. (ed) (1970) Coronary heart disease in seven countries. Circulation, 41 (suppl. 1), 174.

Keys, A. (1973) Letter to the editors. Atherosclerosis, 18, 352.

Keys, A., Anderson, J.T., Mickelson, O., Adelson, S.F. \& FIDANZA, F. (1956) Diet and serum cholesterol: lack of effect of dietary cholesterol. Journal of Nutrition, 59, 39.

Keys, A., Aravanis, C., Blackburn, H., van Buchem, F.S.P. Buzina, R., DJordjevic, B.S., Fidanza, F., Karvonen, M.J., Menotti, A., Puddu, V. \& TAYlor, H.L. (1972) Coronary heart disease: overweight and obesity as risk factors. Annals of Internal Medicine, 77, 15.

Keys, A., Grande, F. \& Anderson, J.T. (1974) Bias and misrepresentation revisited: perspective on saturated fat. American Journal of Clinical Nutrition, 27, 188.

Keys, A., Karvonen, M.J. \& Fidanza, F. (1958) Serum cholesterol studies in Finland. Lancet, ii, 175.

Klatsky, A.L., Friedman, G.D. \& Siegelaub, A.B. (1973) Coffee drinking prior to acute myocardial infarction. Results from the Kaiser-Permanente study. Journal of the American Medical Association, 226, 540.

Korman, M.G., Ellefson, R.D. \& Hofman, A.F. (1975) Fasting serum bile acid levels in the primary hyperlipoproteinaemias. Proceedings. Mayo Clinic, 50, 76.

LEREN, P. (1966) The effect of plasma cholesterol lowering diet in male survivors of myocardial infarction. Acta medica scandinavica (suppl. 466), 36.

Lewis, B. \& Chait. A. (1974) Personal communication.

Liebow, I.M., BARTSCH, G.E. \& INSUll, W., JR (1965) Relationship of gross myocardial infarction to severity of coronary atherosclerosis in the young male. American Heart Journal, 70, 54.

LiEbowitz, J.O. (1970) The History of Coronary Heart Disease. London: Wellcome Institute of the History of Medicine.

Macdonald, I. \& Braithwaite, D.M. (1964) The influence of dietary carbohydrates and fats on fasting serum lipids. Clinical Science, 27, 23.

Malmros, H. (1969) Dietary prevention of atherosclerosis. Lancet, ii, 479.
ManN, G.V. \& Spoerry, A. (1974) Studies of a surfactant and cholesteremia in the Masai. American Journal of Clinical Nutrition, 27, 464.

ManN, G.V., Shaffer, R.D. \& Rich, A. (1965) Physical fitness and immunity to heart disease in Masai. Lancet, ii, 1308.

ManN, J.I. \& Truswell, A.S. (1972) Effects of isocaloric exchange of dietary sucrose and starch on fasting serum lipids, postprandial insulin secretion and alimentary lipaemia in human subjects. British Journal of Nutrition, 27, 395.

ManN, J.I., Truswell, A.S. \& Manning, E.B. (1972) Effects on serum lipids of reducing dietary sucrose or starch for 22 weeks in normal men. South African Medical Journal, 46, 827.

ManN, J.I., Truswell, A.S., Hendricks, D.A. \& Manning, E. (1970) Effects on serum lipids in normal men of reducing dietary sucrose or starch for five months. Lancet, i, 870.

MASIRONI, R. (1970) Dietary factors and coronary heart disease. Bulletin of the World Health Organization, 42, 103.

Masironi, R., Miesch, A. T., Crawford, M.D. \& Hamilton, E.I. (1973) Geochemical environments, trace elements and cardiovascular diseases. Bulletin of the Pan-American Health Organization, 7, 53.

MAYER, J. (1973) Heart disease: plans for action. In: US Nutrition Policies in the Seventies (Ed. by J. Mayer), p. 44. San Francisco: W. H. Freeman.

Medical Boards of Finland, Norway and Sweden (1969) quoted In: Davidson, S., Passmore, R., Brock, J.F. \& Truswell, A.S. (1975) Human Nutrition and Dietetics, 6th Edn, p. 652. Edinburgh and London: Churchill Livingstone.

MEYERS, D. (1975) Ischaemic heart disease and the water factor. A variable relationship. British Journal of Preventive and Social Medicine, 29, 98.

Morris, J.N., Kagan, A., Pattison, D.C., Gardner, M.J. \& RAFFle, P.A.B. (1966) Incidence and prediction of ischaemic heart-disease in London busmen. Lancet, ii, 553.

Morris, J.N., Marr, J.W., Heady, J.A., Mills, G.L. \& Pilkington, T.R.E. (1963) Diet and plasma cholesterol in 99 bank men. British Medical Journal, 1, 571.

National Heart Foundation of Australia. Committee on Diet and Heart Disease (1974) Dietary fat and coronary heart disease: a review. Medical Journal of Australia, 1,$575 ; 616 ; 663$.

National Heart Foundation of New Zealand (1971) Coronary Heart Disease. A New Zealand Report. Dunedin, N.Z.: John McIndoe Ltd.

Oscai, L.B., Patterson, J.A., Bogard, D.L., Beck, R.J. \& ROTHERMEL, B.L. (1972) Normalization of serum triglycerides and lipoprotein electrophoretic patterns by exercise. American Journal of Cardiology, 30, 775.

Paul, O., Lepper, M.H., Phelan, W.H., Duppertus, G.W., Macmillan, A., McKean, H. \& Park, H. (1963) A longitudinal study of coronary heart disease. Circulation, 28, 20.

REPORT OF A CoMmittee of THE Royal Society OF NeW Zealand (1971) Coronary Heart Disease. Wellington, N.Z.: The Royal Society of New Zealand.

RIES, W. (1973) Feeding behaviour in obesity. Proceedings of of the Nutrition Society, 32, 187.

Royal Colleges of Physicians and British Cardiac SocIETY (1976) Primary prevention of coronary heart disease. Report of a Working Party. Journal of the Royal College of Physicians of London, 10, 213.

ShaPER, A.G. (1972) Cardiovascular disease in the tropics. IV. Coronary heart disease. British Medical Journal, 4, 32.

Strong, J.P., Solberg, L.A. \& Restrepo, C. (1968) Atherosclerosis in persons with coronary heart disease. Laboratory Investigation, 18, 527. 
Sturdevant, R.A.L., Pearce, M.L. \& Dayton, S. (1973) Increased prevalance of cholelithiasis in men ingesting a serum cholesterol-lowering diet. New England Journal of Medicine, 288, 24.

Truswell, A.S. (1975) Fat and fatty oils. Nutritional and medical aspects. Reports of the Progress of Applied Chemistry during 1973, 58, 459. London: Academic Press.

Truswell, A.S. (1976) Review and Recommendations on Nutrition, Food Science and Technology, Training and Research in Ghana, Kenya, Sierra Leone, Sudan and Tanzania. Accra, Ghana: FAO Regional Office for Africa.

Truswell, A.S. \& KAY, R.M. (1975) Absence of effect of bran on blood-lipids. Lancet, i, 922.

Truswell, A.S. \& MANN, J.I. (1972) Epidemiology of serum lipids in southern Africa. Atherosclerosis, 16, 15.

Truswell, A.S., Kennelly, B.M., Hansen, J.D.L. \& Lee, R.B. (1972) Blood pressures of Kung bushmen in Northern Botswana. American Heart Journal, 84, 5.
Trowell, H. (1972) Ischaemic heart disease and dietary fiber. American Journal of Clinical Nutrition, 25, 926.

VoEdINGSRAAD (1973) Advies over hoeveelheid en/of aard der vetter in de voeding. Ministerie van Volksgesondheid en $\unrhd$ Milieuhygiene. 's-Gravenhage, The Netherlands: Staat- $\underset{.}{.}$ suitgeverij.

WORCESTER, N.A., BRUCKDORFER, K.R. \& YUdKIN, J. (1975a) The effect of dietary sucrose and dietary cholesterol on hyperlipidaemia and atherosclerosis in White Leghorn cockerels (Gallus domesticus). Proceedings of the Nutrition Society, 34, 81A.

WORCESTER, N.A., Bruckdorfer, K.R. \& YudKin, J. (1975b) The effect of dietary sugar and hydrogenated coconut oil on atherosclerosis in Dutch belted rabbits (Oryctolagus cuniculus). Proceedings of the Nutrition Society, 34, 125.

YUDKIN, J. (1964) Dietary fat and dietary sugar in relation to ischaemic heart disease and diabetes. Lancet, ii, 4.

YUDKIN, J. (1968) Dietary sugar and serum cholesterol. Lancet, $\mathbf{i}, 917$. 